\title{
Proselytizing the Prague Manifesto in Britain: The Commissioning, Conception, and Musical Language of Alan Bush's "Nottingham" Symphony
}

\author{
JULIE WATERS
}

In 1949 the City of Nottingham held a week of celebrations commemorating the quincentenary of its Royal Charter of Freedom. A musical centerpiece of the celebrations was the premiere of Alan Bush's Second Symphony, the "Nottingham." Commissioned by the Nottingham Co-operative Society (NCS), a trading organization associated with the labour movement, the symphony was first performed on June 27 in the city's Albert Hall by the London Philharmonic Orchestra. ${ }^{1}$ The symphony was dedicated to the people of Nottingham and a bound copy of the score was presented to the Lord Mayor.

Bush's early reputation had been gained as the composer of difficult and complex works influenced by central European musical idioms, but after World War II he had become increasingly interested in making his music more accessible and national in character. ${ }^{2}$ By June 1949 he had composed two concertos, two symphonies, and much orchestral, chamber, and vocal music. He was actively engaged in British musical life as composition teacher (Professor at the Royal Academy of Music), pianist, conductor, examiner, writer, and committee member of numerous British musical organizations, including the Composers' Guild and British Council Music Advisory Committee. He was also a committed Marxist and member of the British Communist Party; his involvement in a wide range of left-wing musical activities included conducting workers' choirs, organizing and composing for workers' pageants, and establishing the Workers' Musical Association (WMA). ${ }^{3}$

The Nottingham Symphony was the first major orchestral work Bush wrote after attending the Second International Congress of Composers and Musicologists in Prague in May 1948 (Prague Congress). His attendance at the Congress was significant because he met with other Marxist composers and signed the document later to be known as the Prague Manifesto. Moreover, he subsequently claimed that his experiences in Prague, in particular, had implications for his compositional approach, and confirmed his view that he should attempt in principle to bring out a "national" character in his music. While Lewis Foreman and others have commented on some aspects of the "Nottingham," it has not been subject to detailed scholarly examination, either with regard to its musical style or its political program. ${ }^{4}$ This article will examine how political and ideological factors helped shape the Nottingham Symphony and, in particular, the extent to

\footnotetext{
${ }^{1}$ The NCS was one of the many consumer co-operative societies in Britain that owned stores and traded for the benefit of consumers.

${ }^{2}$ Colin Mason, Hugo Cole and Derek Watson, "Bush, Alan," in the New Grove Dictionary of Music and Musicians, 2nd ed., eds.

Stanley Sadie and John Tyrrell (London: Macmillan, 2001), 4: 657.

${ }^{3}$ For further information on Bush's life and works, see Stewart Craggs, Alan Bush: A Source Book (Aldershot, Hants: Ashgate, 2007); Rachel O'Higgins, The Correspondence of Alan Bush and John Ireland, 1927-1961 (Aldershot, Hants: Ashgate, 2006); Nancy Bush, Alan Bush: Music, Politics and Life (London: Thames Publishing, 2000); Lewis Foreman, "Spanning the Century," in Nancy Bush, 98-145; Ronald Stevenson, ed., Alan Bush - An 80th Birthday Symposium (Kidderminster: Bravura, 1981); Alan Bush, In My Eighth Decade and Other Essays (London: Kahn \& Averill, 1980); Alan Bush Music Trust Website, http://www.alanbushtrust.org.uk/, accessed 8 August 2007.

${ }^{4}$ E.g. Lewis Foreman, "Alan Bush (1900-1995) Symphonies Nos. 1 \& 2," Program note (Classico Class CD484, "The British Symphonic Collection," vol. 13, 2004); David Ellenberg, "The Form of the Nottingham Symphony," in WMA, Tribute to Alan Bush on his 50th Birthday: A Symposium (London: WMA, 1950), 45-48.
} 
which the Prague Manifesto, and the socialist realist principles that underlay it, impacted on the symphony's commissioning, conception and musical language.

\section{PART I: Conceptual Framework and Commissioning of the Symphony}

\section{The Prague Manifesto, socialist realism, and Bush's response}

The Prague Manifesto is sometimes treated as if it were synonymous with the notorious Zhdanov Decree. ${ }^{5}$ However, as will be suggested below, there are some significant differences. The Zhdanov Decree of February 10, 1948 is the name given to resolutions of the Central Committee of the Soviet Communist Party. These followed a Conference of Soviet Composers in January, presided over by cultural commissar Andrei Zhdanov. The Decree attacked Shostakovich, Prokofiev, and other leading Soviet composers for their "anti-national" and "anti-democratic" tendencies, for "trampling on the best traditions of Russian and western classical music," for preaching "atonality, dissonance and disharmony, supposedly representative of "progress' and "modernism," "and for "a one-sided cultivation of complex forms of instrumental wordless symphonic music" at the expense of vocal music. ${ }^{6}$ Instead, Soviet composers were directed to write in a more accessible idiom, to draw for musical models on the classical heritage, especially nineteenth-century Russian composers, and also to look to folk music. The cornerstone of the Decree was the doctrine of socialist realism, first defined in the Soviet Writers' Conference of 1934 as being "a true and historically concrete depiction of reality in its revolutionary development," which must be "combined with the task of educating the workers in the spirit of Communism."7

Like the Zhdanov Decree, the Prague Manifesto was based on the assumption that music should be used for political ends. ${ }^{8}$ The Manifesto declared that there was a "crisis" in contemporary music and that this was manifest in public hostility towards serious music and in a gap between serious and popular music. In response, it called for a renewed attention to musical education and for the creation of an "International Association of Progressive Composers and Musicologists" (IAPCM). It also called on composers to employ an accessible musical idiom (basically, one that was direct and classical in form, and avoided avant-garde techniques), to convey the ideas and aspirations of the "broad masses," to draw on the national culture of the composer's own country, and to adopt genres capable of more "concrete content" (such as opera, cantata, and song). ${ }^{9}$ There are clearly similarities with the Decree, particularly in the Manifesto's rejection of modernism. However, the Manifesto differed from the Decree in several critical respects: first, it was drafted by composers rather than a Party bureaucrat (even if two of the Soviet delegates, Tikhon Khrennikov and Boris

\footnotetext{
${ }^{5}$ E.g. Nathaniel Lew observes that the Zhdanov "regime was further promulgated" at the Prague Congress. "A New and Glorious Age: Constructions of National Opera in Britain, 1945-1951" ( PhD diss., University of California, Berkeley, 2001), 499-500. For recent important critical discussions of the Manifesto see Mark Carroll, Music and Ideology in Cold War Europe (Cambridge: Cambridge University Press, 2003) and Jaromir Havlik, "The Prague Manifesto after (almost) Sixty Years," Czech Music (2007), available from http://goliath.ecnext.com/coms2/gi 0199-6731791/The-Prague-Manifesto-after-almost.html, accessed 18 August 2007. Havlik in particular considers some of the differences between both documents.

${ }^{6}$ Nicolas Slonimsky, Music Since 1900, 5th ed. (New York: Schirmer Books, 1994), 1056. An English translation of the text of the Decree is in Slonimsky, 1055-57. Two major sources on the Decree are Alexander Werth, Musical Uproar in Moscow (London: Turnstile Press, 1949); and Boris Schwarz, Music and Musical Life in Soviet Russia 1917-1981, enlarged ed. (First printed 1972; Bloomington: Indiana University Press, 1983).

${ }^{7}$ Cited in Vaughan James, Soviet Socialist Realism: Origins and Theory (London: The Macmillan Press, 1973), ix.

${ }^{8}$ See Carroll, 37. For further commentary on Zhdanov and the Manifesto, see Carroll, 39.

${ }^{9}$ The translation used in this article is from the printed document entitled "Proclamation and Resolution of the Second International Congress of Composers and Music Critics held in Prague, May 20th to 29th, 1948," found in the uncatalogued Bush Archive at the British Library (hereafter all references to this archive are identified as "BMSSBL"). The document (BL Manifesto) contains the translation of the Prague Resolution. The Manifesto is also included in English translation in Slonimsky, 1068. However, Slonimsky does not contain a translation of the Resolution.
} 
Yarustovsky, occupied prominent positions in the Soviet musical and political hierarchy); second, it was more constructive and less dogmatic in tone; and third, it left open which national styles should be adopted, rather than prescribing classical Russian nineteenth-century models. ${ }^{10}$ More importantly, it expressed the genuine desire of many Marxist composers to communicate to a broader audience and to write music that was socially committed. ${ }^{11}$

The Prague Congress, organized by the Syndicate of Czech Composers (SCC), was attended by about seventy composers from the Soviet Union, Eastern Bloc, and other countries. These included Tikhon Khrennikov from the Soviet Union, Hanns Eisler representing Austria, and Bernard Stevens of Britain. Although Bush claimed that Eisler played a key part in drafting the Manifesto, Bush himself was keenly involved in the discussions. ${ }^{12}$ Indeed, Czech musicologists Milos Juzl and Jaromir Havlik have singled out Bush's contribution as seminal. ${ }^{13}$ Not only did he submit a paper to be read there, entitled "Structure and Expression of Modern Music," but he was one of the twenty-one signatories to the Manifesto and Resolution (signed on the same day as the Manifesto). ${ }^{14} \mathrm{He}$ was also on the Executive Committee of the Congress and on the inception committee of the new IAPCM. Under the terms of the Resolution Bush had a duty to inform "progressive" composers in Britain about the ideas in the Manifesto and to create a British section of the IAPCM. (It should be noted that the term "progressive" was commonly used by left-wing writers to denote those working towards a socialist future.) He also had an obligation to work towards putting the terms of the Manifesto into practice. ${ }^{15}$

So what steps did Bush take to implement the Manifesto on his return to Britain in June 1948? Space constraints mean that only a brief sketch of the answers to this question can be given here. Within Britain, Bush used the press to promote the ideas expressed in the Manifesto. For example, he outlined the Congress findings and the Manifesto's principles in an article published in the September 1948 issue of the Musical Times. ${ }^{16}$ He publicly defended the Zhdanov Decree, which had attracted considerable hostile attention in Britain, in an article ("Soviet Music") in the spring issue of the Anglo-Soviet Journal, attempting to define "formalism" and justifying the attacks on Shostakovich and other Soviet composers. ${ }^{17}$ In another article ("A Remarkable Document") in the autumn issue of the same journal he claimed that the Decree summed up, as far as Soviet musical practice was concerned, "the theories of Marxism in relation to the development of music." 18 Moreover, he forcefully criticized the unfavourable account given of the Decree in Alexander Werth's book, Musical Uproar in Moscow, though without advancing any really convincing arguments in defence of the Decree. He was also active on the organizational front. Having been Chairman of the Composers' Guild between 1947 and 1948, he was involved in an attempt by extreme left-wing British

\footnotetext{
${ }^{10}$ The issue of Soviet influence on the Manifesto is a contested one. Some writers support the notion of Soviet domination, while others argue that the Soviet influence was not strong enough to dictate to the entire Congress. Representative of the first view is Elizabeth Janik, Recomposing German Music: Politics and Tradition in Cold War Berlin (Leiden, Boston: Brill, 2005), 205; representative of the second view is Milos Juzl, "Music and the Totalitarian Regime in Czechoslovakia," International Review of the Aesthetics and Sociology of Music 27, no. 1 (1996): 37.

${ }^{11}$ For perspectives on the idealism associated with socialist realism, see Christopher Norris, "Socialist Realism," in the New Grove Dictionary of Music and Musicians, 2nd edition, ed. Stanley Sadie and John Tyrrell (London: Macmillan, 2001), 23: 599-600; Anne Shreffler, "Review of Socialist Realism and Music; Zwischen Macht und Freiheit; Musik zwischen Emigration und Stalinismus;

Nationale Musik im 20. Jahrehundert," in Journal of the American Musicological Society 60, no. 2 (2007): 460.

${ }^{12}$ See David Blake, ed. Hanns Eisler: A Miscellany (Australia: Harwood Academic Publisher, 1995), 155.

${ }^{13}$ Juzl, 38; Havlik.

${ }^{14}$ Bush to Syndicate of Czech Composers (SCC), 21 April 1948, BMSSBL.

${ }^{15}$ This obligation was set out in a letter dated 2 June 1948 from the SCC Executive Committee to Bush. A further letter dated 6 June 1948 from the SCC (BMSSBL) referred to him beginning "intensive propaganda and preparation in line with the Proclamation and Resolution."

16 “The Second International Congress of Composers and Music Critics," Musical Times 89, no. 1267 (1948): 280-1.

17 "Soviet Music," Anglo-Soviet Journal 10, no. 1 (Spring 1949): 32-34.

18 “A Remarkable Document," Anglo-Soviet Journal 10, no. 3 (Autumn 1949): 19-20.
} 
composers to have the Guild endorse the Manifesto. This provoked huge controversy within the Guild and was ultimately unsuccessful. ${ }^{19}$

The central importance of the Manifesto for Bush was its stance on musical style and aesthetics. In later years he stated that the discussions at Prague, together with discussions on the Zhdanov Decree, had significantly influenced his compositional approach. Yet it was his attendance at Prague which was the decisive factor, for it was at Prague that the idea of national musical culture was fore-grounded and he was able to discuss musical problems with like-minded composers. The ideas Bush developed in Prague confirmed his commitment to a more accessible idiom and to an English "national" style in music, a style whose influences included English folksong and Tudor polyphony. He had begun moving in this direction earlier in the 1940s with works such as the English Suite. ${ }^{20}$ However, it was arguably not until after the Prague Congress that he chose the idea of a national style as a matter of principle as well as practice. ${ }^{21}$

\section{Commissioning of the symphony: Music for the People}

The Nottingham Symphony was composed in just over three months. Bush began writing it on January 13, 1949 and completed it on May 13, taking three weeks off to fulfil a conducting engagement in Bulgaria. ${ }^{22}$ He was acutely conscious of the "shortness of time," and feared that the work "could hardly turn out entirely well." However, while not making large claims, he wrote in July to his friend, composer John Ireland, that he felt he had produced "the right sort of thing for the occasion." 23

Given the immediacy of the Prague Congress and Bush's positive response, it is not surprising that the circumstances in which the "Nottingham" was commissioned and produced were weighted with political and ideological import for him. The commission was of great significance to Bush because he perceived in the involvement of the labour co-operative movement an innovative alternative to the old system of private patronage and the newer one of State funding. He hoped that the commission would create a "precedent" which would be "followed by other peoples" organizations." 24 The commission fee was $£ 400$ - a very substantial sum in 1949. Bush was anxious that financial details of the commission should be made public (to which the NCS agreed) because he viewed music as an activity having social and economic implications. ${ }^{25}$

Indeed, he regarded the commission as a step forward in the fight for composers' rights, which he saw as including the right to greater financial support from the community. He had long been a tireless advocate for these rights, and had spent a considerable amount of time between 1947 and 1948 attempting to renegotiate a model contract with publishers on behalf of the Composers' Guild. His belief that composers should retain copyright in their compositions was reflected in his contractual arrangements concerning the "Nottingham." Bush expressly agreed with the NCS that he would retain copyright in the work. ${ }^{26}$ Consequently, he was able to claim to his publishers that he had a legal obligation not to relinquish copyright

\footnotetext{
${ }^{19}$ See William Alwyn, "Notes in Retrospect," in Stevenson, 112.

${ }^{20}$ This shift has been noted by various commentators. These include the anonymous writer on "Alan Bush," London Philharmonic Post (July/August 4, 1949): 3-4; and Foreman, "Spanning the Century," 116.

${ }^{21}$ On 29 June 1965 (BMSSBL) Bush wrote to Ronald Stevenson that it was after the Prague Congress that he arrived at the theory that "national differences" should be "sought for in principle." Stevenson, with whom Bush maintained a close friendship, also stressed the importance of the Congress in Bush's development. "Alan Bush: Committed Composer," The Music Review 25, no. 4 (1964): 328. So too did Bush's friend Alwyn, (in Stevenson, 112). However, in an interview with Murray Schafer in 1963, Bush said that the resolutions taken at the 1948 Conference of Russian Composers, presided over by Zhdanov, gave him a "further clarification on points that were worrying" him, and convinced him that he should "make a more determined effort to bring out a national character" in his music. Schafer, British Composers in Interview (London: Faber \& Faber, 1963), 58-59.

${ }^{22}$ The dates are from a file note in the Bush Archive Histon (BAH), Cambridge.

${ }^{23}$ Bush to John Ireland, 11 July 1949, O’Higgins, 221.

${ }^{24}$ H.G.S, "Where Robin Hood Once Roamed," Reynolds, 26 June 1949.

${ }^{25}$ Bush to NCS, 24 February 1949, BMSSBL.

${ }^{26}$ Bush to NCS, 12 January 1949, BMSSBL.
} 
in the "Nottingham" to them. ${ }^{27}$ This was particularly significant in view of his refusal two months earlier to assign the rights in his Piers Ploughman's Suite, on the basis that it was "unwise" for a composer to surrender copyright to a publisher. ${ }^{28}$

Although Bush was an established composer, he received the commission essentially because of a sympathetic left-wing presence in, or associated with, the NCS, and because of his longstanding relationship, through his work with workers' choirs and in musical education, with the British co-operative movement. ${ }^{29}$ A particularly fruitful connection was Bush's friendship with David Ellenberg, who conducted the first performance of the symphony. Ellenberg, the music director of NCS's Arts Centre and the People's Theatre, was also involved with Bush in various activities associated with the WMA and the Communist Party. It was Ellenberg who suggested to the NCS that it should commission Bush. The previous year, also on Ellenberg's suggestion, Bush had written Our Song especially for the opening of the Arts Centre on November 7, $1948 .^{30}$

In some ways the NCS commission may be seen as part of the Labour Party's post-war support of the arts for working people, which historian Nick Hayes argues is encapsulated in "the educational ethos promoted by the co-operative movement." 31 The NCS, whose aims extended beyond the economic and social to the cultural and educational, already had a considerable musical involvement, including a musical director, orchestra, and choir. ${ }^{32}$ Based on the notion of co-operative endeavor "for the betterment of the community," the NCS was in fact much more than a trading organization. ${ }^{33}$ According to Francis Leeman, who chronicled its official history, co-operation was "a way of life, its commandments being ... the principle applied by the Rochdale Pioneers in 1844." ${ }^{34}$

Cyril Forsyth, the NCS's chief executive officer and managing secretary from 1944 to 1963, has been described as "a charismatic figure passionately committed to the arts." 35 It was Forsyth who put the idea of the symphony to the Quincentenary special committee, offered the commission on behalf of the NCS, and negotiated the commission with Bush. Forsyth was not only influential in the city's Labour Party but also, possibly, a communist sympathizer. ${ }^{36}$ What effect did Forsyth's political leanings have on Bush's approach to the commission? Clearly the celebratory nature of the commission would have influenced the symphony's affirmative nature. However, the first and third movements of the symphony had political undertones (see discussion below). In this context it is relevant to note an article by music journalist H.G. Sear which appeared on March 7, 1949 in the communist newspaper, the Daily Worker:

The secretary of the Nottingham Co-Op, though apparently oblivious of the recent Soviet musical controversy, made this point ... He ventured to hope that the composer of The Nottingham Symphony,

\footnotetext{
${ }^{27}$ Bush to Joseph Willliams, 5 June 1949, BMSSBL.

${ }^{28}$ Bush to Joseph Williams, 16 April 1949, BMSSBL.

${ }^{29}$ The Co-op Education Committees and the Co-op choirs had been important representatives at the inaugural meeting of the WMA, founded by Bush in 1936. See Thomas Russell, "The Nottingham Symphony," in WMA, Tribute to Alan Bush, 41, on the philanthropic element in Bush's involvement in workers' music.

${ }^{30}$ Nancy Bush, 62.

${ }^{31}$ See Nick Hayes, "Municipal Subsidy and Tory Minimalism: Building the Nottingham Playhouse, 1942-1963," Midland History 19 (1994): 132, available from http://www.midlandhistory.bham.ac.uk/issues/1994/index.htm, accessed 8 February, 2008.

${ }^{32}$ Russell, 41.

${ }^{33}$ Cyril Forsyth, foreword to brochure on Nottingham Symphony published by the NCS in 1949 ("Nottingham brochure"), 1.

${ }^{34}$ Co-operation in Nottingham: A History of One Hundred Years of Nottingham Co-operative Society Ltd. ([Nottingham]: Nottingham Co-operative Society [1963]), 144. The Rochdale Pioneers had believed in the establishment of self-supporting local communities of united interests which would "produce, consume and gain the benefits of education in common." See G.D.H. Cole, The British Co-Operative Movement in a Socialist Society (London: George Allen \& Unwin, 1951), 28.

${ }^{35}$ Hayes, 132.

${ }^{36}$ Forsyth as initiating and offering commission, see Reynolds, 26 June 1949; and city Labour Party, Hayes, 132. According to Ted Perfect (retired long-time employee of NCS), Forsyth was a "keen member" of the Communist Party. Email from Perfect to Rachel O’Higgins, 30 November 2005, BAH.
} 
without pandering to musical ignorance, would have in mind, not a handful of musical gourmets but a wide range of folk who love music. ${ }^{37}$

Sear does not mention Forsyth's alleged political leanings and therefore that he was likely to have been familiar with the "Soviet musical controversy" (Zhdanov Decree). However, it is significant that in discussing the symphony Forsyth used language ("handful of musical gourmets") that closely resembled that used in the Decree ("a narrow circle of specialists and musical epicures"). ${ }^{38}$ Forsyth's views were also consistent with the Prague Manifesto's call on composers to bridge the gap between serious and light music, and combine "craftsmanship, originality and high quality with genuine popular appeal.",39

\section{PART II: The Prague Manifesto and the Symphony's Musical Language}

In his dissertation on English opera, part of which focuses on Bush's Wat Tyler (written 1948-50), Nathaniel Lew claims that the "forceful imposition" of socialist realism in 1948 and Bush's attempts to bring his works in accord with this, had a "profound influence on his compositional output." ${ }^{40}$ Part II of this article, by testing the "Nottingham" against the Manifesto and Soviet aesthetic theory, will consider Lew's proposition in relation to the symphony's compositional language. Focusing on the concepts of genre, socialist "content," accessibility, and national culture, it will show that the "Nottingham" is to a large extent consistent with the Manifesto's principal tenets. Certainly, the symphony demonstrates a stylistic shift away from the complexity of Bush's earlier works such as the Piano Concerto (1937) and from his flirtation with serialism in the First Symphony (1940) and the Violin Concerto (1948). ${ }^{41}$

\section{Bush's conception of the "Nottingham" Symphony}

An article written by Bush in July 1949 provides testimony that his aims in the "Nottingham" were in harmony with those of the Manifesto. Writing in the London Philharmonic Post that composers must abandon the notion of art for arts' sake and become aware of their social obligations, Bush specifically related this proposition to the Nottingham Symphony:

The public must ... [make] demands upon us, which we should then try to meet. It is exactly such a demand as this that was set me when the Nottingham Co-operative Society commissioned me to compose a symphony for the City of Nottingham. ${ }^{42}$

In language that reflected the Manifesto's rejection of modernism, Bush wrote that he had "tried consciously to avoid those ingredients in the music of the last forty years which have repelled the public." He also wrote that he had "chosen for the most part scales and intervals characteristic of our own English folk music." ${ }^{43} \mathrm{He}$ thus aimed to compose a popular work that responded to the central principles of the Manifesto, including its focus on national culture and anti-modernism.

Other contemporaneous writings by Bush about the "Nottingham" employ language that resonates strongly with the utopian aspirations of socialist realism, reinforcing the notion that this significantly shaped

\footnotetext{
37 “Nottingham's Symphony,” Daily Worker, 7 March 1949.

${ }^{38}$ Slonimsky, 1056.

${ }^{39}$ BL Manifesto.

${ }^{40}$ Lew, 488.

${ }^{41}$ While parts of the Violin Concerto drew on a twelve tone row, though to tonal effect, much of the work was written before May 1948.

${ }^{42}$ London Philharmonic Post (July/August 4, 1949): 5.

43 Ibid.
} 
his conception of the symphony. For example, in a letter to Forsyth, Bush stated that his aim was to compose a work which would "convey various aspects of the life of the people of Nottingham" whose history was "one of continuous progress towards a brighter future." 44 This reference to "continuous progress" and "a brighter future" echoes the language of the Manifesto, particularly the Manifesto's reference to the "progressive" function of music, and human culture "advancing into a higher stage." 45 Indeed, as musicologist Anne Shreffler notes, socialist realism "resonated with the genuine aspirations of many leftwing composers to write socially progressive music that would be modern and also comprehensible to a large public."46

\section{Programmatic genre and socialist "content"}

Although socialist realism was never clearly defined in the Soviet Union, its central elements were "ideological commitment" (ideinost), "party-mindedness" (partiinost), and "national/popular spirit" (narodnost). According to Leonid Heller, ideological commitment in relation to music meant basically that the form of a work and its musical elements were determined by a governing idea, and this idea was socialist. ${ }^{47}$ In assuming a relationship between music and politics, Bush lined up with the communist States on one side of a musical divide that existed during the Cold War, which opposed social engagement to the view, common in the West, that music was autonomous. ${ }^{48}$

The concept of ideological commitment found expression in the Manifesto's precept that composers should adopt genres capable of "concrete content," music that accompanied text like opera, oratorio, or song. This had been official policy in the Soviet Union since the $1930 \mathrm{~s} .{ }^{49}$ Not only did it mean that a work could be checked for ideological correctness, but it made it easier for Soviet politicians to control an art that required specialist training to understand. ${ }^{50}$ As Bush also observed, "the concrete necessities of the text" were there to prevent the composer from slipping into formalism. ${ }^{51}$ In the case of instrumental works, the requirement for "concrete content" was partly satisfied if the work was programmatic, whether by way of title, text, dedication, or other verbal indication. The program symphony was one of the favored socialist realist genres. In Zhdanov's words, "Russian classical music was as a rule program music." 52 Pauline Fairclough also claims that the idea of the symphony itself as inherently "collective" (in the sense of acting as a socially binding force) had been commonly held in the Soviet Union from the 1920s. ${ }^{53}$

The Nottingham Symphony is, as its title suggests, a work whose program is obviously linked with the nature of Bush's commission. ${ }^{54}$ This connection notwithstanding, it employs the four-movement architecture of the classical symphony and traditional forms within this overall scheme. Although they are named after Nottingham locations, the four movements are identified by traditional Italian terms (respectively Moderato,

\footnotetext{
${ }^{44}$ Bush to NCS, 12 January 1949, BMSSBL.

${ }^{45}$ BL Manifesto.

${ }^{46}$ Shreffler, 460.

${ }^{47}$ Leonid Heller, "A World of Prettiness: Socialist Realism and its Aesthetic Categories," in "Socialist Realism Without Shores: Special Issue," The South Atlantic Quarterly 94, no. 3 (Summer 1995): 688-9.

${ }^{48}$ For discussion of this East/West divide, see Shreffler, 456; for preoccupations common to musicians on both sides, see Carroll, esp., 37.

${ }_{49}$ Boris Schwarz, "Soviet Music since the Second World War," Musical Quarterly 51, no. 3 (1966): 269.

${ }^{50} \mathrm{Juzl}, 50$.

${ }^{51}$ Bush, "Soviet Music," 33.

${ }^{52}$ Andrei Zhdanov, On Literature, Music and Philosophy (London: Lawrence \& Wishart, 1950), 63.

${ }^{53}$ Pauline Fairclough, "The "Perestroyka" of Soviet Symphonism: Shostakovich in 1935," Music \& Letters 83, no. 2 (2002): 265.

${ }^{54}$ The score on which the following discussion is based is a copy of the original that is held in BAH. The author understands that this was made from a photostat copy taken from the original manuscript. The original manuscript (presented to City of Nottingham and meant to be held in the city archives) has been lost. The work is available in a manuscript hire copy from Stainer and Bell. A copy may also be accessed at the British Music Information Centre.
} 
Largo, Allegro Molto, and Allegro Moderato). A brochure prepared for the work's premiere contains detailed program notes based on an analysis provided by Bush. According to this exegesis, three of the movements are guided by variants of sonata form: the first and fourth make use of sonata form with introduction; the second employs an abridged sonata form with introduction. The third movement is a scherzo (moto perpetuo) comprising passacaglia, fugato, and shortened passacaglia. ${ }^{55}$

Bush spent an intensive three days researching Nottingham history and legend as preparation for composing the symphony. By January 12, 1949 he had decided to name each of the four movements after a particular place in Nottingham associated with different aspects of past and present Nottingham life. ${ }^{56}$ The first and third movements were "intended to recall" the peoples" "struggles in the middle ages and in the period of the industrial revolution." The first movement ("Sherwood Forest") referred to the legend of Robin Hood "and his fight against the oppressors of his day," while the third, ("Castle Rock"), was inspired by the burning down of Nottingham Castle by the locals in protest against the Duke of Newcastle's opposition to the 1832 Reform Bill. ${ }^{57}$ Complementing key moments of the city's past, the other movements captured elements of its continuing present. The second movement ("Clifton Grove") evoked Clifton Grove, a popular trysting place at the foot of the River Trent, while the final movement ("Goose Fair") celebrated Nottingham's annual fair. While not "political," these two movements were intended to express people's feelings in, and the atmosphere of, personal and social life. In presenting images of a mythical, historical, pastoral, and festive English landscape in a symphony dedicated to an industrialized modern city, Bush thus set up a dichotomy between rural and urban, past, and present.

The composer's political intent (as discussed above) was spelled out in a "Message to the People of Nottingham" which he never sent. Bush was more circumspect in the brochure published for the work's premiere, which focused largely on the symphony's form and musical language, though the political associations of the third movement had in fact been made known in the press. ${ }^{58}$ Considered overall, however, the content of the symphony was in line with a central tenet of the Manifesto: the notion that a work should express the ideas and aspirations of the "broad masses." This was linked with the Soviet concept of "partymindedness." Party-mindedness essentially meant that a work had to convey an active and "aggressive" form of socialism, one that contributed to the building of communism. ${ }^{59}$ In text-centered works such as opera this could be conveyed by presenting a heroic figure; in purely instrumental works it was more difficult. How did Bush express party-mindedness in the "Nottingham"? One way was to associate the music with ideas about social struggle, and convey an emotional response to this in musical terms.

Misconceptions about Bush's program and its content led to some early criticism of the third movement. One anonymous reviewer, taking the title ("Castle Rock") as a cue, suggested that the musical form was ill-suited to conveying the craggy splendour of Nottingham Castle. The reviewer, apparently ignorant of Bush's aim to convey the atmosphere and emotion of social protest, saw the movement as "calling for the massively majestic, not for a scurrying moto perpetuo." 60 The jubilant and abrupt fortissimo ending, with its staccato cadence on the third beat, leaves the listener with a sense of victory. At the same time it conveys a sense of forward momentum. This not only works well musically, in keeping with the

\footnotetext{
${ }^{55}$ See Nottingham brochure, 7-12. The analysis is a valuable guide to the symphony and informs the analytical approach in this article. A commentary on the symphony containing material from the program note is located at http://www.alanbushtrust.org.uk/music/compositions/OR.asp?room=Music, accessed 12 May 2006.

${ }^{56}$ Bush to NCS, 12 January 1949, BMSSBL.

57 "Message to the People of Nottingham," unpublished paper marked "Not Sent," located in BAH.

${ }^{58}$ E.g. Sear, Daily Worker.

${ }^{59}$ Heller, 689.

60 “Nottingham Hears its Own Symphony,” Nottingham Guardian, 28 June 1949.
} 
controlled agitation that characterizes the movement, but is consistent with Bush's desire to convey a sense of optimism.

The need for music to be optimistic was an integral part of the doctrine of socialist realism. The fourth movement ("Goose Fair"), ending "in a mood of purposeful optimism," is even more patently the expression of a celebratory mood. The introduction begins by expressing the disorder and festive nature of the annual Nottingham fair. As the program note states, a number of thematic motives, spread out over the introduction, are initially presented simultaneously. These are then developed in a more systematic fashion as the movement proceeds. ${ }^{61}$ Cross rhythms and contrapuntal treatment of the melodies are used effectively to convey the initial sense of confusion. However, the movement is dominated by a "festal march theme" (at first in the trumpet part) which constitutes the first subject and is developed extensively later. The metaphorical program might thus be described as the celebration of disorder brought to order, of progress towards a socialist future.

The dominance of the march idea in the finale recalls numerous Soviet symphonies which similarly used marches or had a triumphant major key ending and thus attempted to satisfy party-mindedness. This movement drew the most adverse reaction from contemporaneous British critics, based on the notion that Bush had been fettered by extra-musical considerations. ${ }^{62}$ Although the movement exhibits a certain brash quality (for example, the use of bells towards the end), it is worth asking whether Bush would have been criticized quite as harshly had he not endorsed Soviet musical aesthetics so publicly. Bush's skill in handling his thematic material is manifest, as he showed in the introduction. Another example is the lyrical second subject (first theme), lasting for 47 bars. Tonally ambiguous, rhythmically fluid, and melodically diffuse [Ex.1], it provides an effective contrast to the tonally secure, rhythmically solid and basically stepwise first subject [Ex.2].

One problem for composers influenced by socialist realism was to create an art characterized by "revolutionary romanticism"- that is, music that was simultaneously both "realist" (showing things as they are) and socialist (depicting things as they might be in a future socialist world). ${ }^{63}$ Bush was plainly aware of the difficulties, as David Ellenberg implied in a letter to him in January 1949 concerning the "Nottingham": "I have been thinking over your remarks about the danger of giving an impression that "Everything is for the best in the best of all possible worlds'," wrote Ellenberg. In a somewhat circular argument, he then attempted to reassure Bush that he could not fall into the "Voltairean trap" because "only a truly progressive person could be genuinely optimistic at the present time," and to "achieve genuine optimism in music today means inevitably to achieve a content which is progressive." 64 The line between representing the "reality" of a socialist utopia without indulging in bourgeois escapism was indeed a fine one.

Perhaps Bush had the first movement ("Sherwood Forest") in mind when worrying about the "Voltairean trap," for this movement confronts one directly with the paradox of twentieth-century Nottingham being represented by a pastoral idyll set in the Middle Ages. According to Bush's program note, the movement represents "the sunny, open spaces of Sherwood Forest in the time of Robin Hood." The introduction begins quietly and expansively with a horn call (rising fifth), a conventional pastoral signifier associated with the image of the forest [Ex.3].

\footnotetext{
${ }^{61}$ Nottingham brochure, 14, 12.

${ }^{62}$ E.g. Charles Reid, "Music," Evening Standard, 12 December 1952; Martin Cooper, "The Politically Purposeful Symphony," Spectator 19 December 1952.

${ }^{63}$ See Bush, "Soviet Music," 33; Norris, 599-600; Fairclough, 260.

${ }^{64}$ David Ellenberg to Bush, 6 January 1949, BMSSBL.
} 


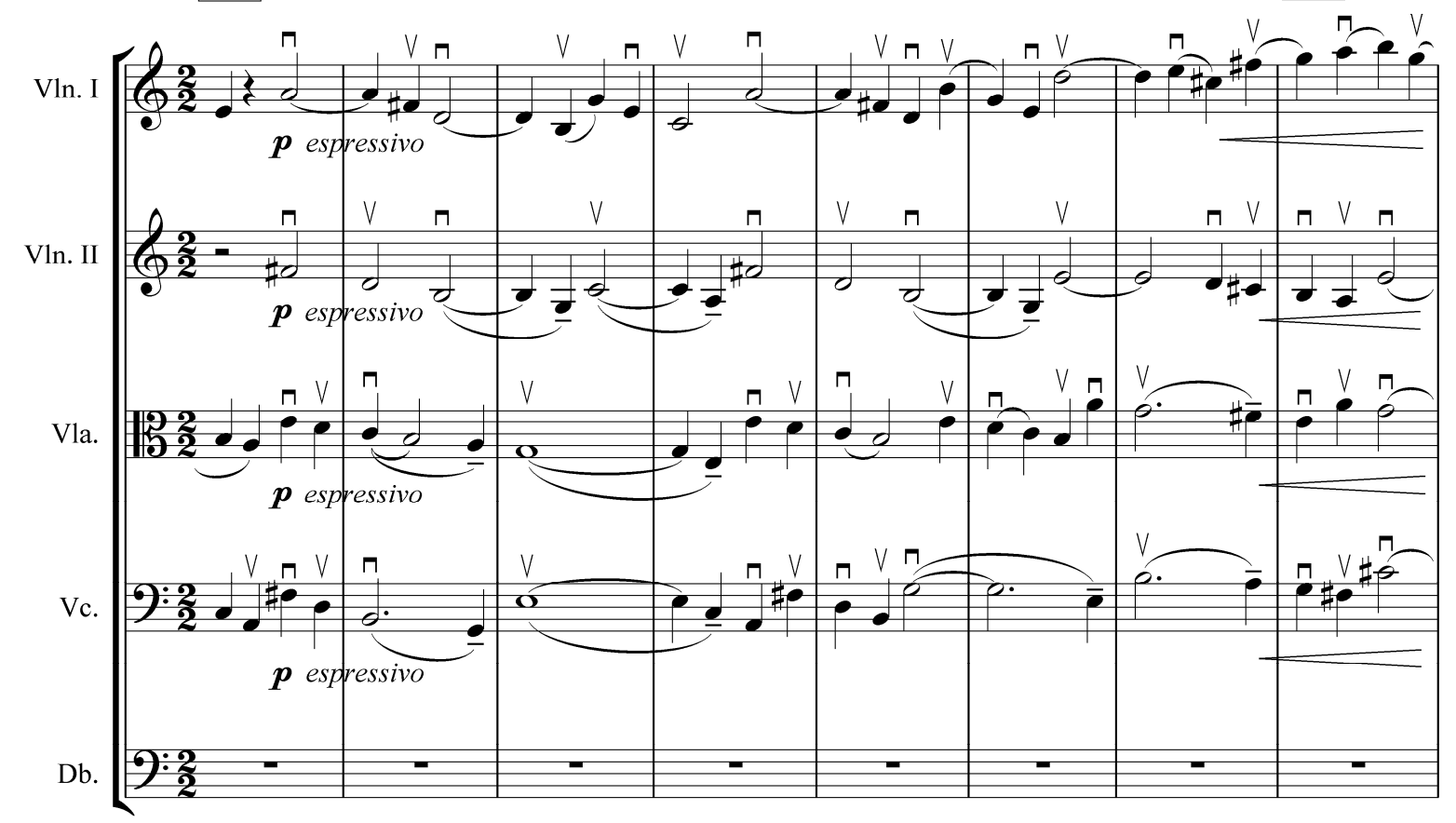

Example 1. Nottingham Symphony: Fourth movement, bars 111-18. Second subject (first theme) in strings

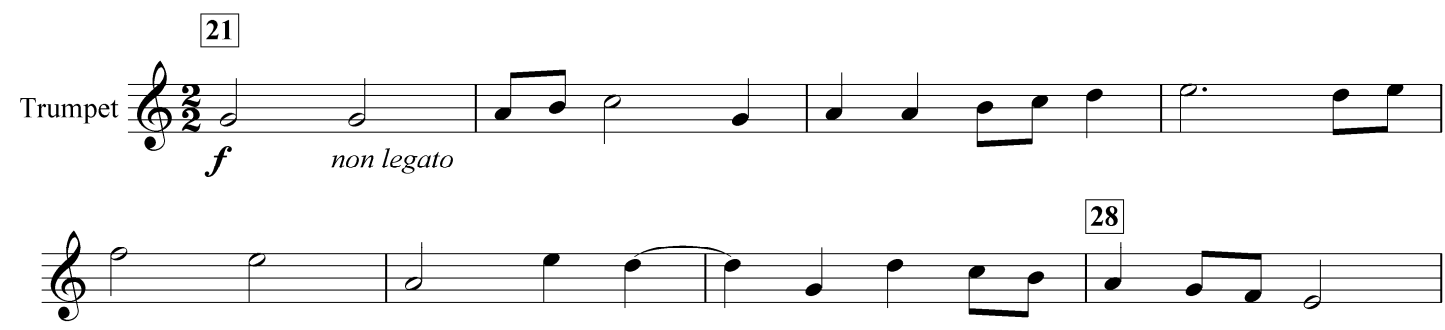

Example 2. Nottingham Symphony: Fourth movement, bars 21-28. First subject in trumpet

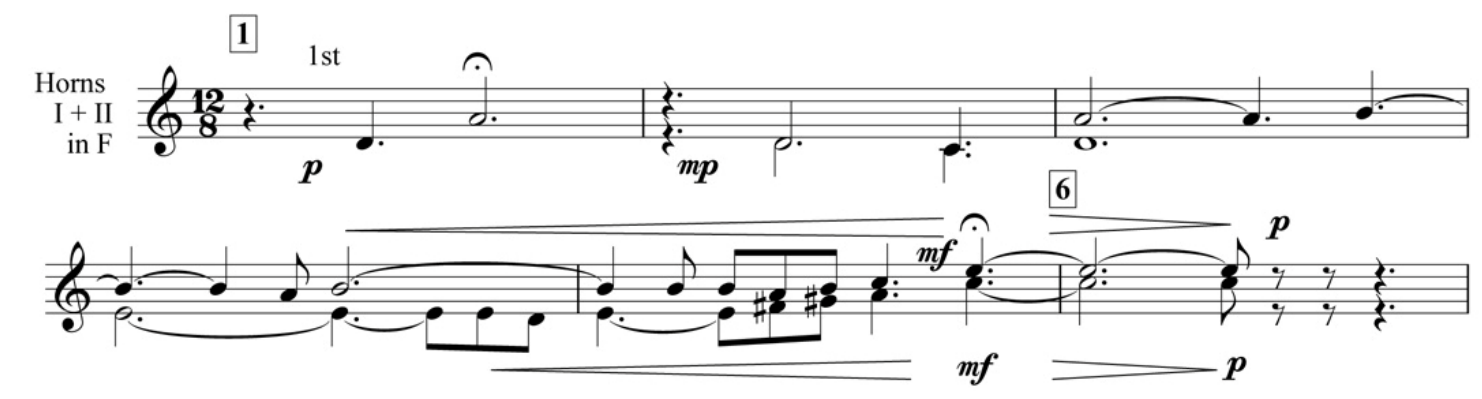

Example 3. Nottingham Symphony: First movement, bars 1-6. Introduction in horn in F (in transposition) 
The serene introduction soon gives way to the lively first subject (Robin Hood theme) in strings and winds [Ex.4]. ${ }^{65}$

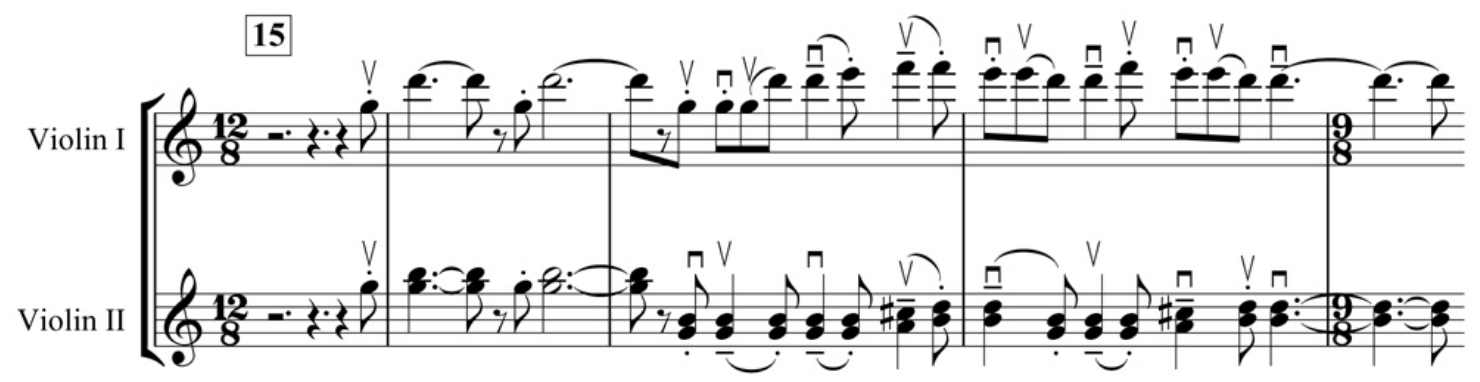

Example 4. Nottingham Symphony: First movement, bars 15-19. First subject in violin I (with "galloping" motif in violin II )

A bucolic mood is conveyed by musical elements such as major mode, compound time, simple melodic contour, and movement by parallel thirds — all which have been noted as typically "pastoral" features. ${ }^{66}$

Most of the material from which the introduction and first subject are constructed is derived from the initial rising fifth, followed by rising and falling seconds. The second subject is also derived from the initial bars of the introduction in diminution [Ex.5] and shares its defining melodic features. This high degree of thematic organization underscores the fact that, even in 1949 and notwithstanding the Soviet strictures against formalism, Bush continued to employ a decidedly abstract approach to composition. He first employed what he called his "thematic method" in the late 1920s. As he explained it, the melodic material for all voice parts was thematically derived (and the theme could include harmonic progressions as well as melodic motifs). ${ }^{67}$

65

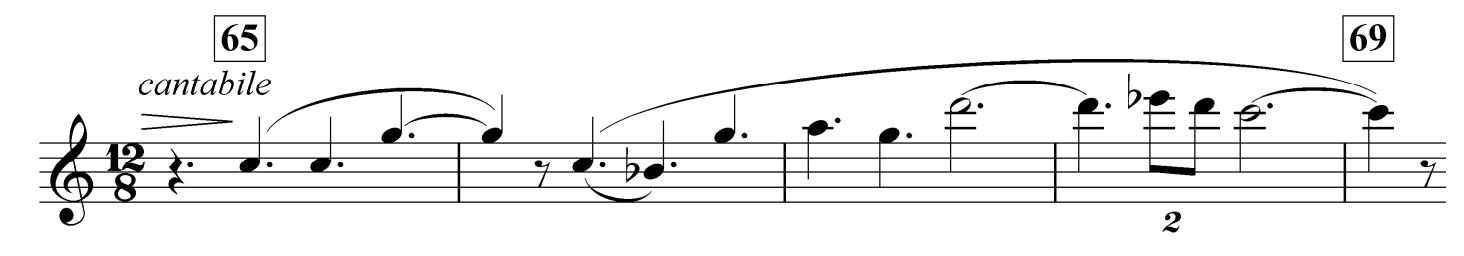

Clarinet

Example 5. Nottingham Symphony: First movement, bars 65-69. Second subject in clarinet in A (in transposition)

The development section of the first movement is more heavily programmatic. Here there is no real working through of material from the exposition; rather, two passages characterized by a recurring horn motif (with fragments of the first subject) alternate with two episodes representing the "sheriff's cavalcade" [Ex.6].

\footnotetext{
${ }^{65}$ Nottingham brochure, 7.

${ }^{66}$ See discussion of pastoral signifiers in Robert Hatten, Beethoven: Markedness, Correlation and Interpretation (Bloomington and Indianapolis: Indiana University Press, 1994), 97-99; and David Wyn Jones, Beethoven Pastoral Symphony (Cambridge: Cambridge University Press, 1995), 14.

${ }^{67}$ Bush explained the method retrospectively, in an article entitled "The Crisis of Modern Music," Keynote 1, no. 4 (1946): 4-7. In the Nottingham brochure, page 7, he referred to the fact that the melodic, harmonic, and bass elements of the symphony "all possess thematic character."
} 


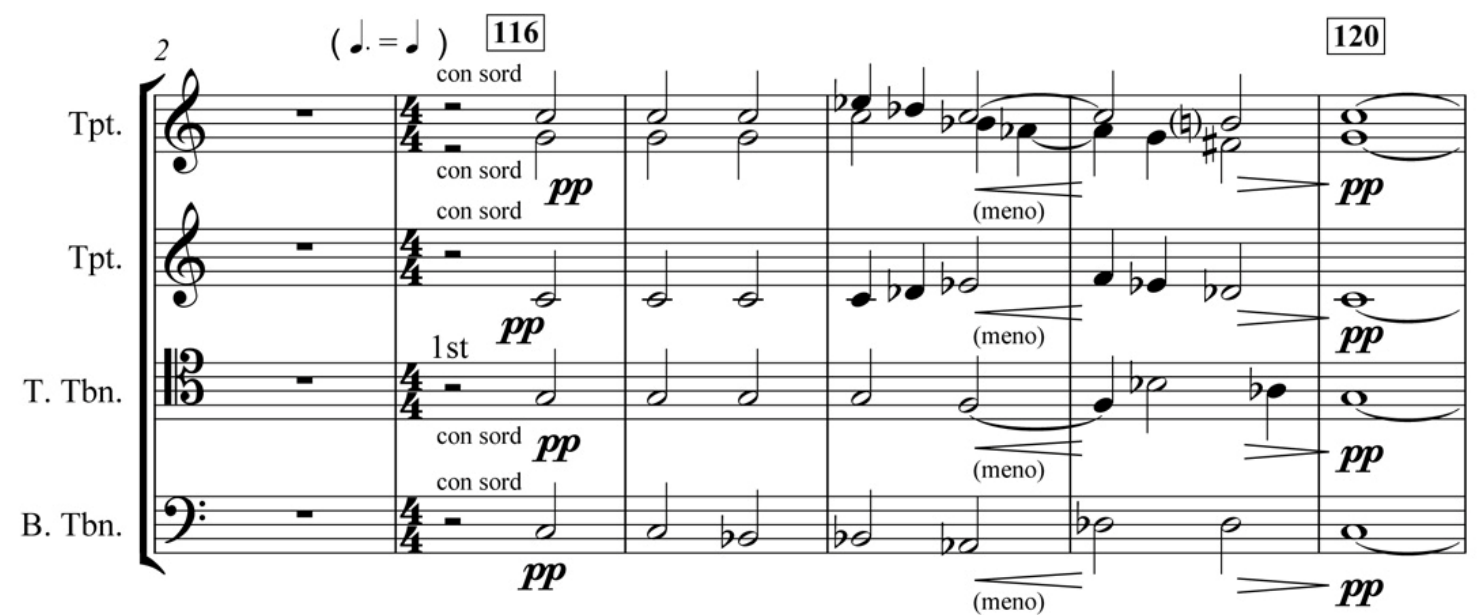

Example 6. Nottingham Symphony: First movement, bars 116-20. Development, with first appearance of "sheriff's cavalcade" episode in brass

Each episode consists of four phrases and is set in sharp relief from the preceding horn passage by virtue of changes in tempo and note value (from fast quaver triplets to slow minims), instrumentation (from strings and wind to brass and percussion) and mode (from no clear tonal direction to a recognizable statement of the Phrygian mode). The steadily increasing dynamic and use of side-drum suggest an armed force gradually drawing nearer. In an attempt to elucidate his meaning Bush hints at a quasi-political message in the program note: at the climax of the development, the rhythm of the Sheriff's motif is "broken down by the attacks of the previous musical material" (Robin Hood theme), achieved by the imposition of a descending triplet crotchet figure in the brass and notes tied over the bar-lines which override the preceding regular minim pattern [Ex.7]. ${ }^{68}$ The movement ends with the evocation once more of the "idyllic" life of Sherwood Forest. ${ }^{69}$

So while the program could be seen as the triumph of subversive forces against the established order, the stress is on the "merry men" of legend rather than serious social commentary. The dichotomy here between mythical landscape and social protest brings to mind the front cover of the Exhibition Handbook published for the Quincentenary, on which, beneath an image of Robin Hood, complete with bow and arrow, lay the title "Industrial Nottingham." Both handbook and symphony underscore the paradox of drawing on an idealized past to represent present reality. In Bush's case it was doubly paradoxical, for by 1949 the national style represented, for example, by the music of Vaughan Williams with its strong pastoral elements was being replaced by a more "internationalist cultural climate" and style. ${ }^{70}$ So why were the pastoral elements of the "Nottingham" not mere escapism? In fact, as will be shown later, Bush arguably looked to English pastoralism to secure his sense of national spirit precisely because this tradition was so firmly identified with English culture. Moreover, he was perhaps following in what Paul Harringtom has identified as the "radical pastoral" tradition in English music, a tradition linking pastoralism, socialism, and nationalism, and exemplified by figures such as Vaughan Williams and Holst. ${ }^{71}$

\footnotetext{
${ }^{68}$ Nottingham brochure, 8 . The reference in this paragraph to horn passages and episodes draws on Bush's characterization.

${ }^{69}$ Nottingham brochure, 8 .

${ }^{70}$ See Arnold Whittall, "British Music in the Modern World," in The Blackwell History of Music in Britain: The Twentieth Century, ed. Stephen Banfield (Oxford: Blackwell, 1995), 15.

${ }^{71}$ See Paul Harrington, "Holst and Vaughan Williams: Radical Pastoral," in Music and the Politics of Culture, ed. Christopher Norris (London: Lawrence \& Wishart, 1989), 106-27. Harrington argues that Vaughan Williams and Holst were influenced in their early years by the socialism of William Morris.
} 


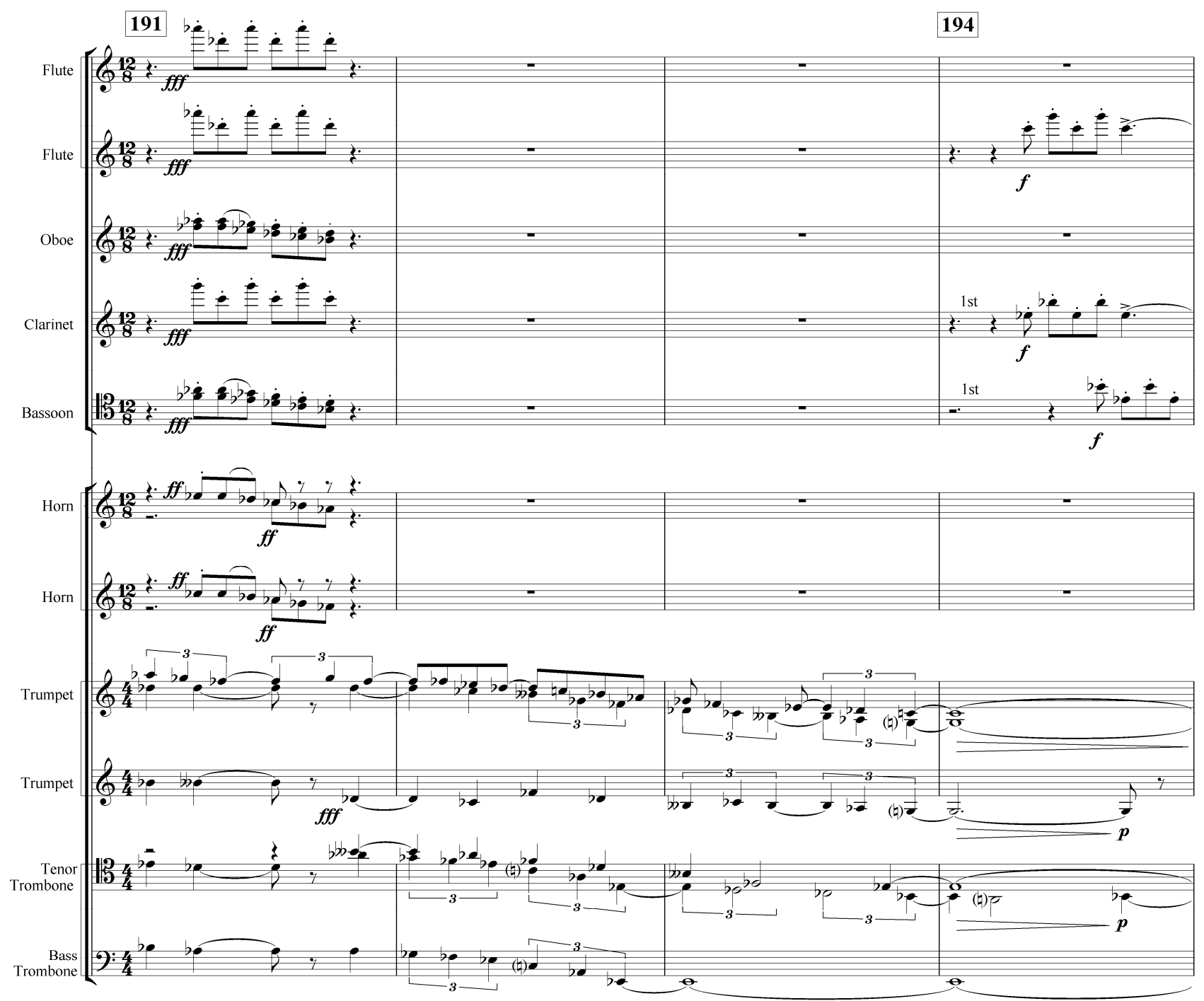

Example 7. Nottingham Symphony: First movement, bars 191-4. Development, demonstrating "breakdown" of rhythm of sheriff's cavalcade theme in brass (not full instrumentation; clarinet in A and horn in F in transposition) 


\section{The Idea of Accessibility}

Part of the radical pastoral tradition of cultural and political commitment was a concern with musical education for working people. ${ }^{72}$ In 1941 Bush had founded the William Morris Musical Society, and after the war he became increasingly preoccupied with a desire to help ordinary people understand serious music. ${ }^{73}$ This concern was linked with the idea of musical accessibility, a simplified version of which was stated by Zhdanov in 1948:

The people assesses a musical composition according to ... how intelligible it is to the wide masses. For what is it in music that is proof of genius? It is not something that can only be grasped by a small group of aesthetes. ${ }^{74}$

So was the people's capacity for appreciation to be elevated, or was the style of music to be simplified? This problem was never resolved in the Manifesto, which supported reducing musical illiteracy yet was opposed to what socialist realism termed "formalism." While formalism in Soviet aesthetic theory was only ever defined negatively, it had connotations of music that was elitist, complex, experimental, or modernist. ${ }^{75}$ Bush, whose earlier art music fitted this description to differing degrees, later saw formalism even in the "Passacaglia" from his English Suite. ${ }^{76}$ Likewise, in an interview with Murray Schafer, he said that he had "accused" himself of formalism after the proceedings of $1948 .^{77}$

According to established canons of socialist realism, music should be tonal and characterized by the employment of classical models, clear forms, simple straightforward melody, and the avoidance of excessive dissonance and complexity. The Nottingham Symphony is in all important respects consistent with these criteria. A work in the tonal center of $\mathrm{G}$, it eschews chromaticism and harsh dissonances. While modes are used extensively, the frequent use of parallel thirds and open fifths tends to reinforce a sense of the tonal. In terms of melodic style the symphony betrays an eclectic range of influences, including folksong (principal subject in the first movement), Soviet socialist realism (march theme in the fourth movement), and nineteenth-century Romanticism (long lyrical second subject in the fourth movement).

Bush's orchestration in the work is often pared down and chamber-like. For example, in the first movement the wind instruments are dominant; the full orchestra is heard only in a short part of the development section, and the movement ends with a relatively light texture. The second movement, being of a quieter and more lyrical nature, is characterized by the sparing use of brass, with the winds and strings assuming equal importance and solo parts given to clarinet and cello. In the third and fourth movements there is increased emphasis on contrapuntal forms and techniques (shown especially in the third movement's passacaglia and fugato and in the highly polyphonic treatment of the principal subject in the fourth movement). The prominence of brass and percussion reinforces the popular appeal and also the more triumphal and public character of these movements.

Bush was determined to make the symphony's musical structure comprehensible. Evidence of this may be seen in the program notes prepared for the work's premiere, which were based on his analysis and contained musical examples. His intention was also demonstrated in a public lecture given prior to the premiere, in which he explained the work's structure and meaning before an appreciative audience at the People's Theatre. ${ }^{78}$ These intentions are confirmed by an examination of formal elements of the symphony.

\footnotetext{
${ }^{72}$ Holst, for example, was involved in working class musical education at Morley College for many years.

${ }^{73}$ See Bush, “Our President's Greeting," Vox Pop 2, no. 1 ( January 1945): 6. In 1946 he helped set up the WMA Summer School.

${ }^{74}$ Zhdanov, 68.

${ }^{75}$ Evan Mawdsley, The Stalin Years: The Soviet Union 1929-1953 (Manchester: Manchester University Press, 1998$), 58$.

${ }^{76}$ Bush to Noel Long, 27 November 1950, BMSSBL.

${ }^{77}$ Schafer, 58.

${ }^{78}$ A report on this lecture ("Symphony Tells of Nottm's Colourful Life and History") appeared in the Nottingham Journal, 14 June 1949.
} 
For example, in the exposition of the fourth movement, the percussion is used to herald in unequivocal terms the entry of the first subject, bridge passage, and second subject (first theme). The sounding of the main themes is made obvious in other ways too, as illustrated by the treatment of the second subject in this movement. Here the second theme of the second subject stands out from the first theme, even though it follows on immediately [Ex.8].

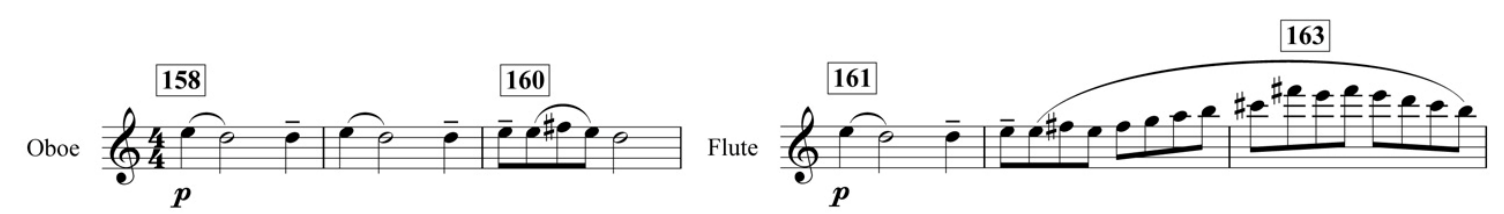

Example 8. Nottingham Symphony: Fourth movement, bars 158-63. Second subject (second theme) in oboe and flute

This signposting is emphasized by contrasts in instrumentation (from strings to winds), melody (long lyrical phrases, followed by a simple, folk-like tune), and texture (dense, followed by transparent). The third movement, beginning with eleven repetitions of the five-bar moto perpetuo passacaglia theme, provides another instance of clear musical structure [Ex.9].

15

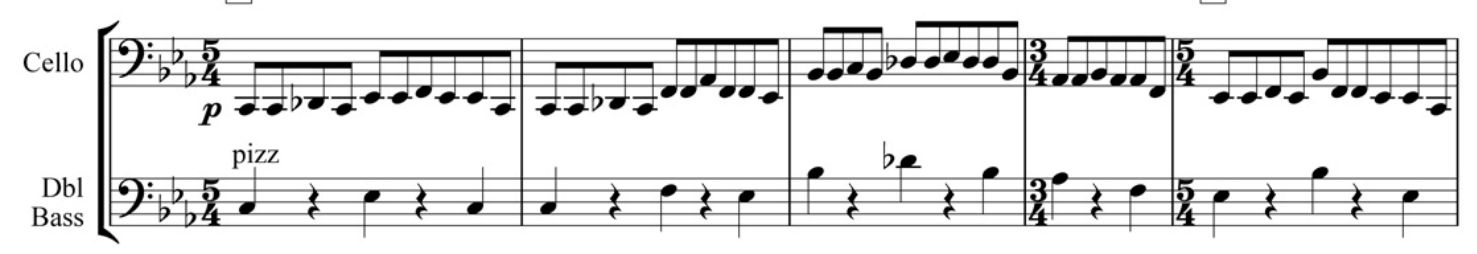

Example 9. Nottingham Symphony: Third movement, bars 1-5. Passacaglia theme in cello

Bush's use of an irregular metrical pattern for his theme (three bars of 5/4, one bar of 3/4, and one bar of 5/4) is highly effective, giving the movement what Artes Orga describes as a "nervously agitated pulse passing through a changing series of metric designs and maintaining an almost regular, yet continually varied, quaver motion." ${ }^{, 79}$ At the same time, the counter-melodies are kept relatively simple so that the music can appeal to a wide audience.

\section{National culture and English national style}

The final tenet of the Prague Manifesto to be considered is the directive that composers should "in their work ally themselves more closely with the national cultures of their countries, defending them against falsely cosmopolitan tendencies, for true internationalism in music can be achieved only by the development of its national characteristics." Expressed in Stalin's maxim that there should be created cultures "national in form and socialist in content," it followed on from the fact that the Soviet Union comprised many national republics and not just the major republic of Russia. ${ }^{81}$ In the case of Soviet composers, the "national/popular culture" requirement generally meant looking to folk music and to the musical language of nineteenth-century Russian composers such as

\footnotetext{
${ }^{79}$ See Artes Orga. “Alan Bush, Musician and Marxist,” Music and Musicians (August 1969): 21.

${ }^{80}$ BL Manifesto. At the time of the Prague Manifesto, the term "cosmopolitan" had negative connotations in the Soviet Union, the main one being a fear of Western influences. Between 1949 and 1953 the term also took on an anti-Semitic element.

81 Stalin's maxim is cited in Marina Frolova-Walker, "National in Form, Socialist in Content," Journal of the American Musicological Society 51, no. 2 (1998): 331.
} 
Tchaikovsky, Mussorgsky, and Rimsky-Korsakov. In the case of Bush and other non-Soviet composers at the Prague Congress, it meant looking to their own national traditions. For Bush it entailed abandoning more radical elements of his earlier style; it also led him to employ a loose set of stylistic and compositional elements drawn on by the English national school of composers. These elements included the modes, contrapuntal techniques derived from sixteenth and seventeenth-century English composers, and programmatic associations with English history, literature, and landscape. It will be suggested later that some of these elements were compatible with earlier features of his style.

Bush's use of English subject matter in the "Nottingham" is obvious, as already discussed. He named the symphony after the city of Nottingham and the movements after Nottingham locations, and drew on English history and legend for his program. Moreover, in so doing he placed himself in line with Vaughan Williams's call in National Music for composers to focus on local subjects and styles. ${ }^{82}$ The second movement, "Clifton Grove," is the one most akin to the English pastoral tradition, largely because of its nostalgic mood and natural setting. ${ }^{83}$ However, here the comparison made has been with Delius rather than Vaughan Williams. ${ }^{84}$ The classic pastoral note is sounded from the outset in the introduction [Ex.10].

The unhurried tempo and quiet dynamic convey a sense of tranquillity; the strings and winds create a wash of sound that evokes the gentle swell of the river. A sense of stasis is further produced by the tonic pedal which extends over the first twenty-five bars. In addition to the obvious suggestion of the river, the introduction exhibits further pastoral characteristics including major mode, repetition of material, and a "rocking" melodic pattern constructed of rising or falling seconds. ${ }^{85}$ Another pastoral element is the evocation of birdsong at the climax of the second subject. This is conveyed musically by the flute in high register, and by a rhythm that makes use of triplet semiquavers and other irregular groupings to suggest a sense of spontaneous song [Ex.11].

\footnotetext{
${ }^{82}$ Ralph Vaughan Williams, National Music and other Essays (London: Oxford University Press, 1963), 9-10.

${ }^{83}$ For a provocative discussion of English pastoralism in music see Meirion Hughes and Robert Stradling, The English Musical Renaissance 1840-1940: Constructing a National Music, 2nd ed. (Manchester: Manchester University Press, 2001), 164-213; for another perspective see Alain Frogley, “'Getting its History Wrong:' English Nationalism and the Reception of Ralph Vaughan Williams," in Music and Nationalism in 20th-Century Great Britain and Finland, ed. Tomi Mäkelä (Hamburg 1997), $145-61$.

${ }^{84}$ Music reviewer Rob Barnett notes that the string writing in this movement is "almost Delian," available from http://www.musicweb-international.com/classRev/2004/July04/Bush_1_2.htm, accessed 14 March 2007. Ronald Stevenson also made the comparison with Delius in a letter to Bush dated September $1 \overline{5}-17,1962$, BMSSBL.

${ }^{85}$ See Hatten, 97-99 and Jones, 14-15, for discussion of pastoral characteristics.
} 


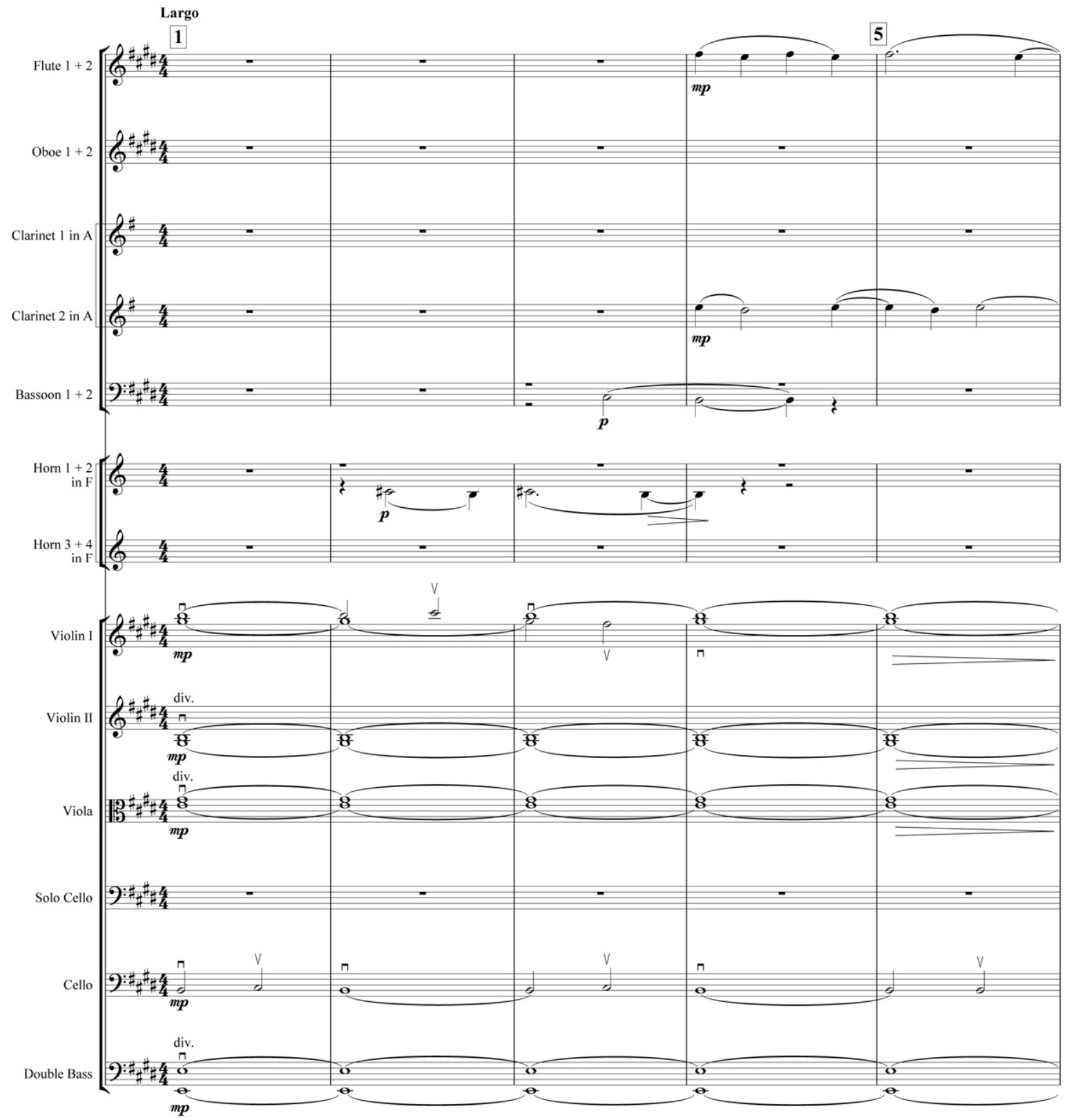

Example 10. Nottingham Symphony: Second movement, bars 1-5. Introduction (clarinet and horn in transposition; brass and percussion omitted as they are not playing)

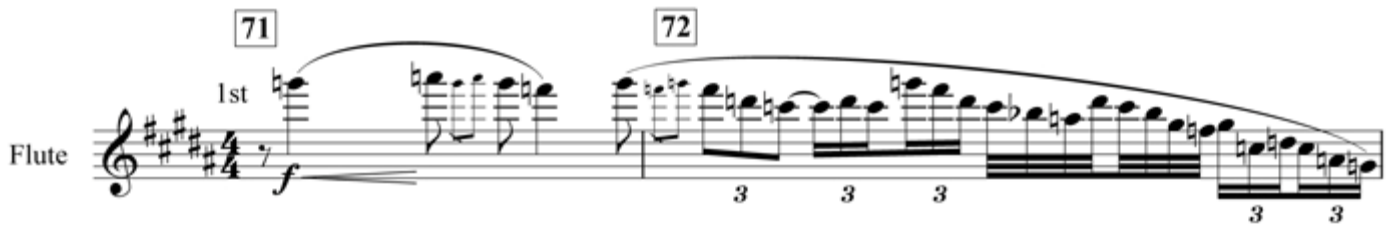

Example 11. Nottingham Symphony: Second movement, bars 71-72. Evocation of birdsong by flute at end of second subject 
The first subject takes the form of a conversation between the solo cello and clarinet [Ex.12]. ${ }^{86}$

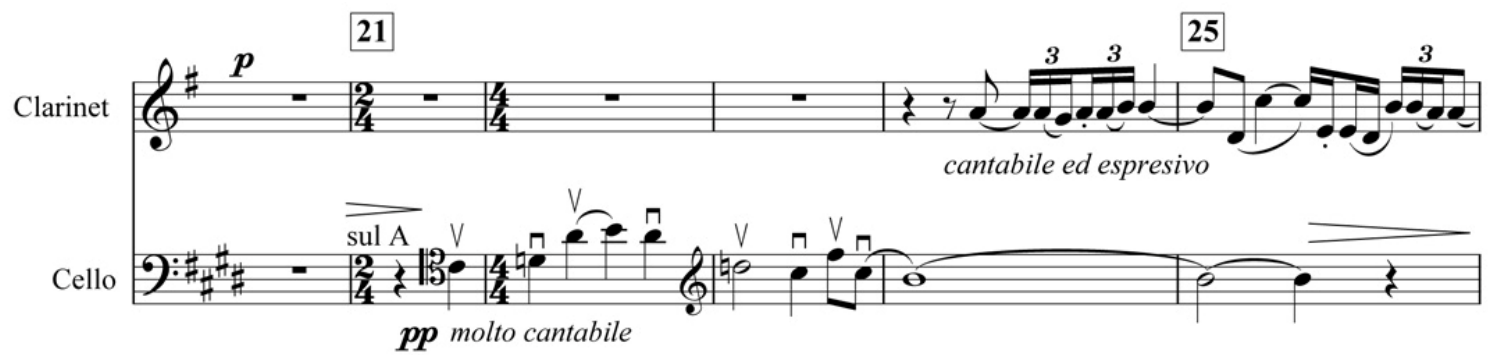

Example 12. Nottingham Symphony: Second movement, bars 21-25. First subject duet between solo cello and clarinet in A (clarinet in transposition)

Bush's portrayal of a courting couple skilfully conveys a sense of play; there is a yearning, wide-ranging melody in the cello, to which the clarinet responds skittishly in a quasi-improvisatory fashion. At two points in the bridge section (bars 42-6, and 49-53) the clarinet breaks away from the cello, moving to a high register with the melody passing to flute and oboe; this is followed by the cello's "sigh" [Ex.13]. The romantic nature of the movement is even more apparent in the presentation of the passionate and lyrical second subject [Ex.14].
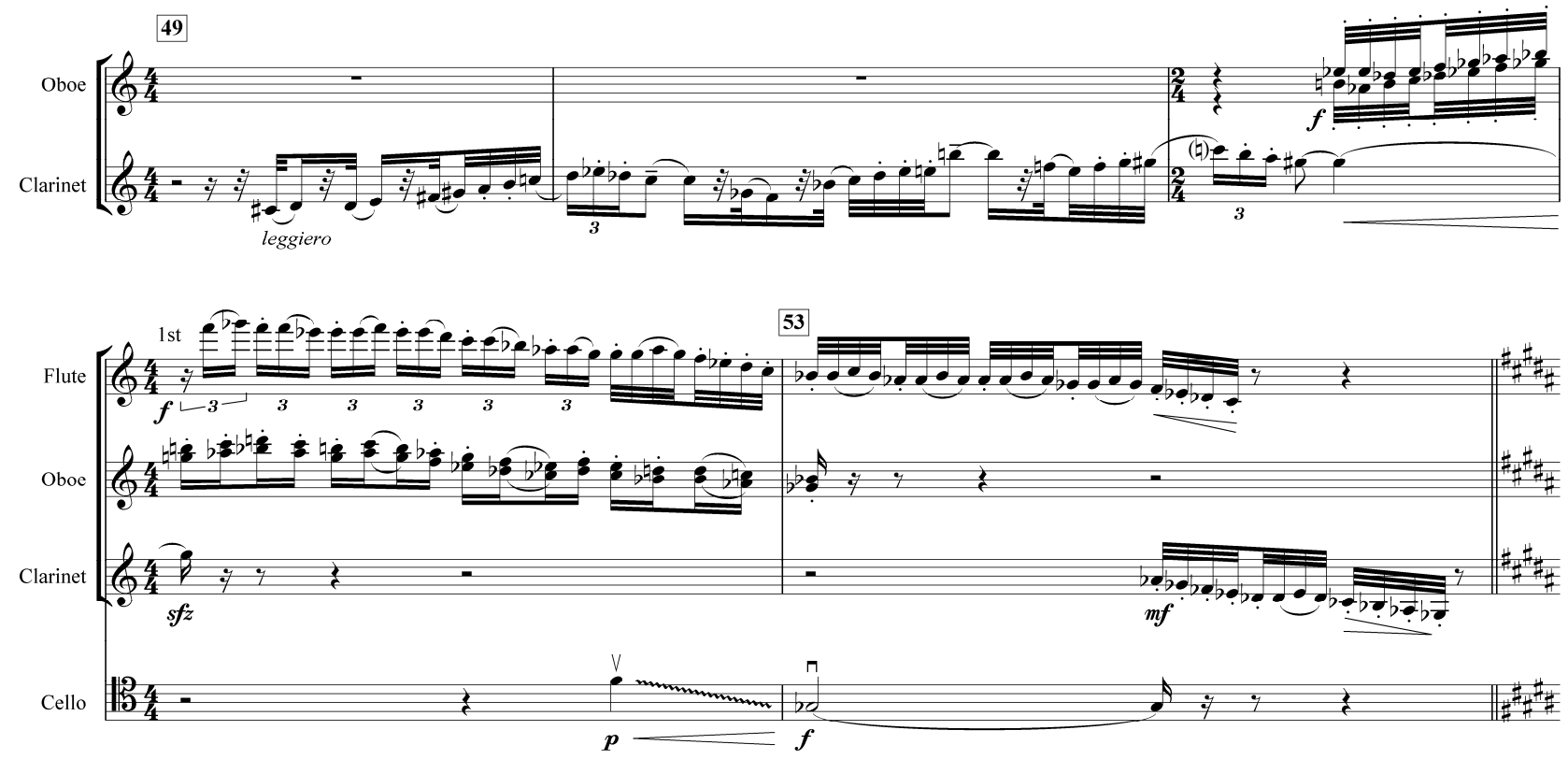

Example 13. Nottingham Symphony: Second movement, bars 49-53. Bridge section, freer clarinet passage taken up by higher winds, cello's "sigh" (clarinet in A in transposition; section of instrumental material)

Bush also looked to the English folk tradition for material, his interest in English folksong having been rekindled by fellow Marxist A.L. Lloyd. Not only had they worked together on a pageant of English folk music in the mid-1940's, but Bush claimed in 1948 that Lloyd's The Singing Englishman was an important Marxist text on music. ${ }^{87}$ In January 1949 Bush wrote to the BBC inquiring about two local folksongs

\footnotetext{
${ }^{86}$ Nottingham brochure, 9.

${ }^{87}$ Bush to Louis Sageur, 23 December 1948, BMSSBL. Lloyd's The Singing Englishman (London: WMA, 1944) was a Marxist account of English folksong.
} 
("Thorneymoor Woods" and "When Shawes are Green") which had appeared on a BBC Birmingham program entitled "Musical Nottinghamshire." 88 He also wrote to the organizer of Maypole dancing at Clifton Village Green, asking whether Maypole dancing had survived through the centuries and whether the music used was indigenous to Nottinghamshire. ${ }^{89}$ However, by February 23 he had dropped the idea of using actual folksongs, having found only three local ones that were known to very few people in Nottingham. He had moreover discovered that only current popular hits were played at Goose Fair. ${ }^{90}$ Nevertheless, folk music influences are arguably present in the "Nottingham," particularly in the first subject of the first movement (with its simple melody and "galloping" rhythm) and the irregular 5/4 rhythm that drives the passacaglia theme in the third movement. ${ }^{91}$

In 1948 Bush published Strict Counterpoint in Palestrina Style. ${ }^{92}$ This text, which involved a study of the ecclesiastical modes and contrapuntal technique, draws attention to another pillar of English national music, namely, Palestrinian counterpoint and English polyphony of the sixteenth and seventeenth centuries. These, too, were important influences on Bush. Indeed, the study of Palestrina (and English folk song) had formed a key part of his musical education with John Ireland, and he had employed a modal idiom in early works such as the String Quartet of $1924 .{ }^{93}$ Bush's indebtedness to Renaissance polyphony is reflected in his blending of modal and key systems in the "Nottingham."94 (One thinks of Tudor composers, such as William Byrd, who bridged the gulf between tonal and modal systems. ${ }^{95}$ ) For example, the second movement begins in $\mathrm{E}$ major but the presence of the flattened seventh in the first subject and recapitulation points strongly to $\mathrm{E}$ mixolydian [Ex.12]. The fourth movement, with a flattened seventh in the first subject, is predominantly in $\mathrm{G}$ Mixolydian [Ex.2]. However, it also moves between G Ionian (raised seventh) and G Lydian (raised fourth). ${ }^{96}$ The Nottingham's third movement, with a $\mathrm{C}$ minor key signature but a prominent flattened second suggesting C Phrygian [Ex.9], demonstrates Bush's mastery in combining both systems. Likewise, his use of the passacaglia idea in this movement suggests that he had creatively absorbed the "seventeenth-century technique of 'divisions on a ground," which Wilfrid Mellers notes particularly in relation to the "Passacaglia" from his English Suite..$^{97}$

\footnotetext{
${ }^{88}$ Bush to Director of Music, BBC, 29 January 1949, BMSSBL.

${ }^{89}$ Bush to Miss Colthorpe, 29 January 1949, BMSSBL.

90 "Scenes of Nott'm Music," Nottingham Journal.

${ }^{91}$ Orga, 21, claims that Bush's preference for this meter had its origins in early English folksongs such as "Searching for Lambs."

${ }^{92}$ See Bush's foreword to Strict Counterpoint in Palestrina Style: A Practical Textbook (London: Joseph Williams, 1948).

${ }^{93}$ Bush, "My Studies and Friendship with John Ireland," 1979, available from http://www.alanbushtrust.org.uk/writing/article_abush2.asp?room=Writing, accessed 8 August 2007.

${ }^{94}$ Bush's program note states that the keys of the four movements are respectively G Major, E Major, C minor and G Major, although he acknowledges that they are not precisely "keys" as such. See Nottingham brochure, 7.

${ }^{95}$ For discussion of this aspect of Byrd see Hilda Andrews, "Elizabethan Keyboard Music: My Ladye Nevells Booke, 1591," Musical Quarterly 16, no. 1 (1930): 59-71.

${ }_{96}$ The presence of the flattened seventh (F natural) in the first movement suggests G mixolydian rather than G Major, although a pervasive $\mathrm{C}$ sharp (particularly in the introduction) gives it a Lydian cast.

${ }^{97}$ See Mellers, "A Note on Alan Bush and the English Tradition," WMA, Tribute, 23. Mellers also mentions the Nottingham in this context. For discussion of Purcell and ground bass see Hugh Miller, "Henry Purcell and the Ground Bass," Music \& Letters 29, no. 4 (1948): 340-7.
} 

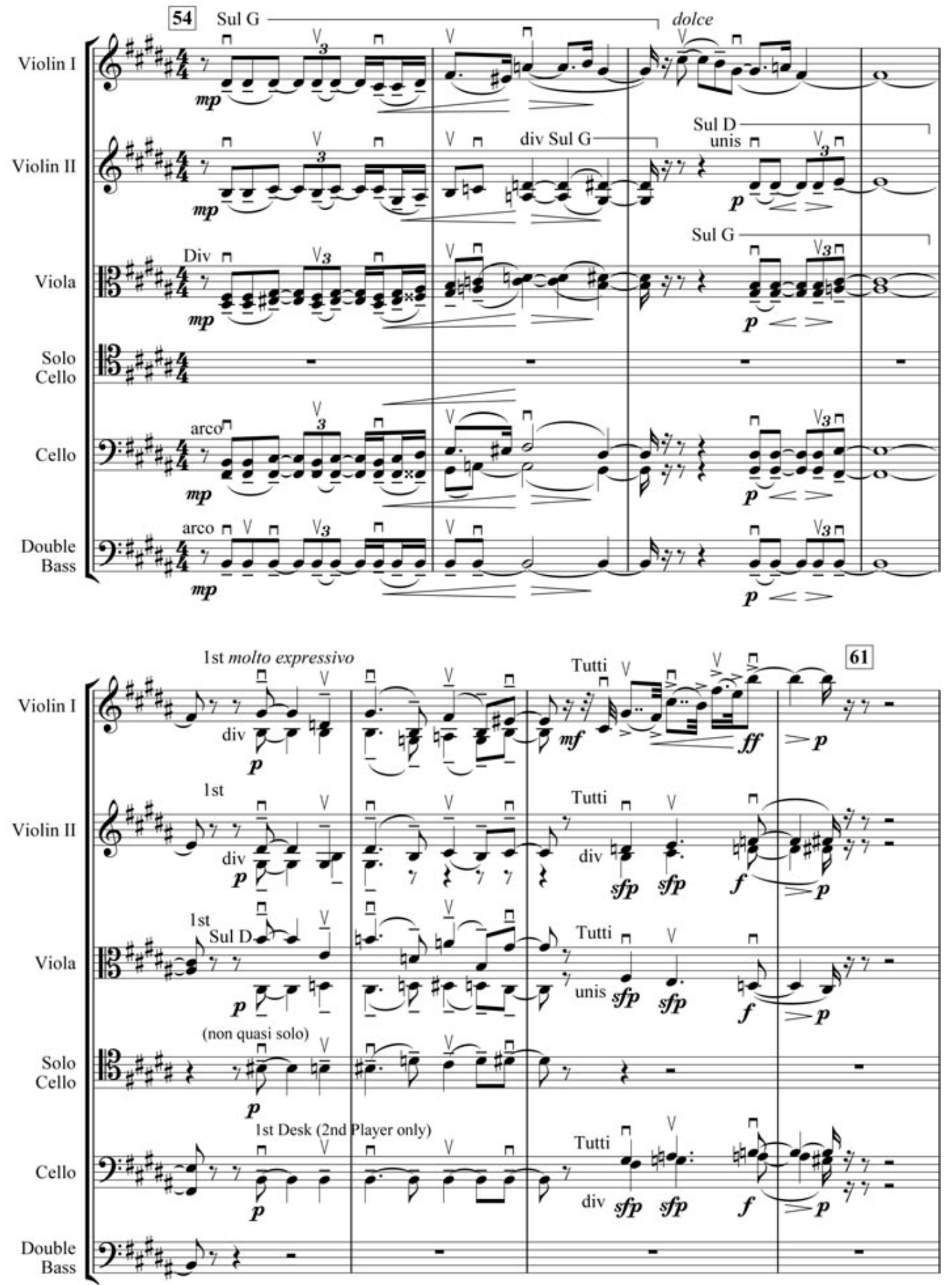

Example 14. Nottingham Symphony: Second movement, bars 54-61. Second subject in strings 
Bush hinted at the link between modes and folk music in 1949 when, in an article dealing partly with the Nottingham Symphony, he wrote that he used the "scales and intervals characteristic of our own English folk music." 98 This reference to "scales" can only be a reference to modes, as was made clear in 1960, when he stated that after 1948 he based his music on the "most characteristic modes and intervals of English folk song." 99 Rather than drawing directly on English folk song in the "Nottingham," then, Bush drew on the modal scales of English folk song, especially Mixolydian and Phrygian. When interviewer Murray Schafer asked him whether he had begun to incorporate more folk music into his work as a result of the events of 1948 Bush replied:

It isn't necessary to use folk music. It would be an absurd misunderstanding of the whole theory of Socialist Realism to assume that it consisted solely in the symphonic development of folk songs. ${ }^{100}$

Bush's rationale for using modes was that "every nation has its own distinctive natural musical 'intonation'." "101 For Bush, as for Vaughan Williams, the modes were an essential part of English national character because of their links with English folk song. ${ }^{102}$

While the anonymous writer in the Philharmonic Post drew attention to the symphony's national elements in July 1949, it was not until the London performance in December 1952 that any pointed reference was made to this aspect. ${ }^{103}$ For instance, the critic in the News Chronicle noted traces of Elgar and Butterworth, while Martin Cooper in the Daily Telegraph placed the "Nottingham" in the context of the "romantic nationalist revivals" and musical "topography." 104 However, by this time critics generally were more preoccupied with the work's populist elements, and the focus, whether explicit or implicit, tended to be on what many saw as the negative impact of Bush's ideological beliefs. ${ }^{105}$

\section{Conclusion}

This article has shown the important part political and ideological factors played in the commissioning and conception of the Nottingham Symphony. By 1949 Bush's commitment to Marxist aesthetics had been intensified by his discussions at the Prague Congress, and publicly demonstrated by his becoming a signatory to, and promoting, the Prague Manifesto. Socialist realism thus provides a crucial framework for understanding the symphony and its musical language. While Bush had already begun traveling down a more national and accessible compositional path earlier in the 1940s, his approach to the symphony reveals his application of the Manifesto's precepts in an English milieu and his composition of a work that was both serious and popular. Viewed in the context of his contemporaneous testimony and actions, Bush's adoption of a more direct musical language, his use of a program having political "content," his drawing on English

\footnotetext{
${ }^{98}$ London Philharmonic Post (July/August 4, 1949): 5.

${ }^{99}$ Colin Mason, “Alan Bush and the Search for a National Style,” Guardian, 1 December 1960, p. 8.

${ }^{100}$ Schafer, 60 .

101 Mason, 8.

${ }^{102}$ However, Bush's use of modes does not possess that distinctive colour immediately conveyed in works such as Vaughan Williams's Fantasia on a Theme of Thomas Tallis.

${ }^{103}$ London Philharmonic Post (July/August 4, 1949): 3-4. However, Mellers (Tribute, 23) had in 1950 mentioned the "Nottingham" in the context of Bush's absorption of national style.

${ }^{104}$ G.D, "Romantic Music Surprises," News Chronicle 12 December 1952; Martin Cooper, "Fashions in Musical Scene-Painting," Daily Telegraph, 27 December 1952. More recently, however, the symphony has been described as a work "far removed from the pastoralism of most English music," see Brian Morton, "Bush, Alan," in Contemporary Composers, eds., Brian Morton and Pamela Collins (Chicago: St James Press, 1992), 145.

${ }^{105}$ Examples of essentially unfavorable reviews include the anonymous critic in the Times ("Nottingham Symphony," 12 December 1952, p. 12); and Martin Cooper, "Music: The Politically Purposeful Symphony," Spectator, 19 December 1952. A more positive review, focusing on Bush's craftsmanship and shift in style away from the "emotional reserve" of earlier works, appeared in the Scotsman ("Nottingham Symphony: Excellent Work by Alan Bush," 13 December 1952).
} 


\section{Music ANd Politics Winter 2009}

national style, and his rejection of avant-garde musical techniques all point to the significant impact of the Manifesto on his musical practice at this time. However, certain elements, including the intensive use of a thematic idea to generate subsequent development, his attraction to polyphony, and his employment of modes, were also consistent with earlier features of his style.

The "Nottingham" opened with evocations of an Arcadian past ("Sherwood Forest") and ended with visions of a Utopian future ("Goose Fair"). Written in 1949, it seems far removed from the cataclysmic years of World War II. Yet, as this article has shown, it bore the insignia of Bush's own musical and ideological journey. It also symbolized two moments in British cultural life: first, a time when the British labour movement aimed to make musical culture available to all, and second, the convergence on British soil of international socialist realism and English national music. Two years later this convergence was confirmed in a new Bush composition, Wat Tyler. Described as a work of "English socialist realism," the opera was a prize-winner in an open, State-sponsored competition to write a national opera for the Festival of Britain. Yet whereas Bush was fortunate in 1949 to have the "Nottingham" publicly performed, Wat Tyler had to wait until 1974 for its stage premiere in Britain. ${ }^{106}$

\section{Acknowledgements}

The author would like to acknowledge with gratitude the generous assistance of Dr Rachel O'Higgins and the Alan Bush Music Trust, and the Reverend John Lowerson, who provided access to relevant materials and much more. The author is also indebted to Dr Kay Dreyfus for her invaluable editorial assistance, and to Dr Nicolas Bell for facilitating access to materials held in the Alan Bush collection of correspondence and papers at the British Library.

\footnotetext{
${ }^{106}$ Lew, 558.
} 


\begin{abstract}
British composer Alan Bush (1900-1995) wrote the "Nottingham" Symphony in 1949. It was the first major orchestral work he wrote after attending the Second International Congress of Composers and Music Critics in Prague in 1948 - a Congress at which the principles of socialist realism were affirmed and national musical traditions upheld as artistic models. Given his Marxist and Communist Party connections and the symphony's pivotal position in his cuvre, the work clearly invites exploration in terms of ideological influences. This article explores the symphony in the context of Bush's view of music as a social activity, and particularly in terms of his response to the Prague Manifesto and Soviet musical aesthetics. Drawing on a range of sources, including Bush's correspondence and publications, the article aims to shed light on the complex interrelationship between his musical theory and practice, and the social and cultural context in which the symphony was created and performed.
\end{abstract}

